\title{
Influence of different co-substrates biochemical composition on raw sludge co-composting
}

Luz Ruggieri, Teresa Gea, Adriana Artola* \& Antoni Sánchez

GICOM: Composting Research Group

Departament d’Enginyeria Química, ETSE, Universitat Autònoma de Barcelona

Edifici Q, Campus UAB. 08913 - Cerdanyola del Vallès (Barcelona, Spain)

* Corresponding Author: Dra. Adriana Artola

Departament d’Enginyeria Química, ETSE, Universitat Autònoma de Barcelona

Edifici Q, Campus UAB. 08913 - Cerdanyola del Vallès (Barcelona, Spain)

Tel.: (34) 93581 4480; Fax: (34) 935812013

E-mail: adriana.artola@uab.cat

Pre-print of Ruggieri, Luz et al. «Influence of different co-substrates biochemical composition on raw sludge co-composting» in Biodegradation (Springer), Vol. 19, Issue 3 (June 2008), p. 403-415.

The final version is available at DOI 10.1007/s10532-007-9146-2 


\section{Abstract}

The influence of biochemical composition of different co-substrates added to raw sludge during co-composting process was studied. The physical properties of the composting mass and their influence on the biological activity were also investigated. Three treatments composed of mixtures of raw sludge and co-substrate (commercial fats, protein, and cellulose) were carried out and compared to a control composed of raw sludge. Mixture conditioning was performed on the basis on air filled porosity (40\%). The results obtained in the co-composting processes reflected a higher biological activity and higher degradation percentages of dry and organic matter when compared with control. Higher temperatures $\left(60,67\right.$ and $62^{\circ} \mathrm{C}$ for fats, protein and cellulose respectively) were also achieved in all co-composting experiments as compared to the control test $\left(55^{\circ} \mathrm{C}\right)$. Biological activity was measured using both Static and Dynamic Respiration Indices obtaining higher values in co-composting experiments compared to the control test. Fats content reduction was higher $(66 \%)$ at higher fats content in the initial mixture (10.6\%). The addition of fats seems also to promote the degradation of cellulose and lignin. Co-composting experiments with fats and cellulose presented higher initial $\mathrm{C} / \mathrm{N}$ ratio and lower nitrogen losses, $27.5 \%$ and $34.2 \%$ compared to $40 \%$ for raw sludge. It has been demonstrated that the addition of an adequate co-substrate to raw sludge leads to a higher degradation percentages of the different biochemical fractions and higher nitrogen conservation.

Keywords: Air filled porosity, Biochemical composition, Co-composting, Respiration indices, Sludge. 


\section{INTRODUCTION}

Composting is a biotechnological process by which different microbial communities initially degrade organic matter into simpler nutrients and, in a second stage, complex organic macromolecules such as humic acids are produced, forming an organic fertilizer known as compost (Hsu and Lo, 1999). Composting is an aerobic process that requires oxygen for microbial degradation and optimum conditions of moisture and porosity. Within the available technologies to recycle organic solid wastes, composting is often presented as a simple and economically-viable process.

Temperature, oxygen, and moisture content are often selected as the control variables in the composting process together with other biochemical, physical and microbiological properties (Haug, 1993). Biological and biochemical indices such as ATP content, enzyme activity and total bacterial counts, among others (Tiquia, 2005), are particularly useful since they relate composting process to metabolic activity. However respirometric methods which determine $\mathrm{CO}_{2}$ evolution or $\mathrm{O}_{2}$ consumption during the degradation process are the most widely used (Barrena et al., 2005). The $\mathrm{O}_{2}$ demand of the composting matrix at the beginning of the process is highly related to the biological activity at this stage where active microorganisms consume easily biodegradable matter (Tremier et al., 2005). Biological activity and thus $\mathrm{O}_{2}$ requirement decrease with composting time reaching stable values when the process is developed under adequate conditions (Adani et al., 2003; Barrena et al., 2006). Methods based on $\mathrm{O}_{2}$ consumption have been classified into dynamic and static protocols (Adani et al., 2001). Dynamic tests imply continuous oxygen supply, whereas in static methods the decay in $\mathrm{O}_{2}$ concentration is determined after the aeration is interrupted (Adani et al., 2006). 
When evaluating a material composting potential optimal physical and chemical characteristics have to be ensured. Co-composting is defined as the addition of a cosubstrate to compensate for deficiencies in the original properties of a material (Díaz et al., 2002). Thus, inadequate $\mathrm{C} / \mathrm{N}$ ratio, low energy content or insufficient porosity can be overcome.

Physical characteristics of the initial mixture are decisive in the composting process. $\mathrm{O}_{2}$ availability for microorganisms should be ensured by providing enough porosity (Malinska and Richard, 2006). Porosity will be partially filled with water which is also necessary for the microbial activity. The ratio between the pore spaces not occupied by water and the total volume of the mixture is called air filled porosity (AFP), a critical parameter to optimize mixture properties in composting processes (Su et al., 2006). AFP values within 30 and 60\% are recommended (Haug, 1993; Annan and White, 1999). Materials that provide a better structure to the mixture by increasing its porosity and AFP (bulking agents) are usually required to achieve adequate values of these parameters. Moisture content, porosity, structure and AFP are interrelated and dependent (Mohee and Mudhoo, 2005). In spite of the significance of AFP in the composting process only few publications reflect its measurement and evolution along the composting process.

$\mathrm{C} / \mathrm{N}$ ratio and biodegradability of organic matter also should be considered when composting is being evaluated as a possible treatment for organic waste materials. Values of C/N ratio within 15-30 are recommended (Haug, 1993). Lower values will promote $\mathrm{N}$ losses in the form of $\mathrm{NH}_{3}$ while higher values can slow down the composting process due to the lack of nitrogen to support microbiological activity. However, it is important to point that the bioavailability of nitrogen and carbon should 
be considered in the calculation of the $\mathrm{C} / \mathrm{N}$ ratio. While nitrogen present in the majority of wastes is mainly found in biodegradable forms, carbon can be present in recalcitrant form (Komilis, 2006; Sánchez, 2007; Zhang et al., 2004). The proportion of readily, moderately and slowly biodegradable organic matter will influence the process kinetics. $\mathrm{pH}$ also affects $\mathrm{N}$ losses by influencing the $\mathrm{NH}_{3}-\mathrm{NH}_{4}{ }^{+}$equilibrium in spite of its direct influence on biological activity (Liang et al., 2006). Co-composting materials with complementary $\mathrm{C} / \mathrm{N}$ ratios can help to reduce nitrogen losses or to prevent process kinetics alteration (Díaz et al., 2002).

The biochemical energy content of the material and its effect on temperature rise has to be considered when pathogen inactivation needs to be ensured. International requirements mandate that temperatures over $55^{\circ} \mathrm{C}$ for a period of two weeks and turning is needed to ensure the pathogen inactivation (US Environmental Protection Agency, 1995). High energy containing materials such as fat-rich wastes can be used as co-substrates when the composting material fails to reach the required pathogen inactivation temperatures (Gea et al., 2006a). On the other hand, temperature influences the microbial population present at each stage of the process. High temperatures maintained for prolonged periods of time seem to promote the degradation of some compounds which under normal conditions of temperature are slowly biodegradable or recalcitrant (Manios et al., 2006).

The aim of this study is to ascertain whether there are any differences between composting raw sludge with different pure biochemical co-substrates (fats, protein and cellulose) and composting of sludge with no co-substrate, in terms of process evolution, degradation of the different biochemical fractions in the composting material, pathogen inactivation potential, nutrient conservation and biological activity improvement. Raw 
sludge has been chosen as basic waste because it is a widely studied residue in the composting field. In addition, AFP has been used as the key parameter in the initial mixture preparation instead of the traditional residue: bulking agent volumetric proportion. To our knowledge, this is the first study conducted with pure composition co-substrates which includes the evolution of all the above parameters at the same time, since most of the composting works are based on the monitoring of one or few of these parameters (Alburquerque et al., 2006a; Baddi et al., 2004; Paredes et al., 2002; Saviozzi et al., 2004). The final goal of the present work is to assess the convenience of using residual materials rich in one of the components considered as co-substrates for sludge composting.

\section{MATERIALS AND METHODS}

\subsection{Composting materials}

Dewatered raw sludge (RS), consisting of primary and activated sludge obtained from the municipal wastewater treatment plant of Sant Feliu de Codines (Barcelona, Spain), was used as substrate for composting experiments. Main characteristics of the RS are summarized in Table 1. Raw sludge was obtained for each experiment directly from the wastewater treatment plant (WWTP) avoiding any storage. Differences in raw sludge composition at the output of the treatment plant were observed (Table 1) due to the intrinsic nature of this residue.

As co-substrates added to RS three different materials were used: animal fats (fats content over 99\%) obtained from a cow slaughterhouse (Trg Debo Fancy, KAO Corporation S.A., Spain), commercial peptone from casein (78.4\%) as source of protein (Scharlau Chemie Microbiology, Spain), and commercial paper paste as source of 
cellulose (over 99\% in cellulose). Wood chips (WC) from a local carpentry were used as bulking agent ground to $1-5 \mathrm{~mm}$ particle size.

The mixtures for the co-composting experiments were prepared by adding different quantities of co-substrate to RS and adjusting air filled porosity (AFP) to $40 \%$ (Annan and White, 1999). This parameter was used instead of the volumetric ratio to prepare the mixtures. Three mixtures, raw sludge with the three pure co-substrates, resulted in different physical structures. Thus, different amounts of wood chips (not registered) was required in each case to obtain the same initial AFP. Nevertheless, in previous experiments it have been observed that wood chips of this size are not biodegraded under laboratory composting conditions (Gea et al., 2003). A control experiment with raw sludge was also conducted to be compared with the co-composting tests. The mixtures were prepared with different material quantities (wet basis) as follows:

Control experiment (C): RS + WC

Co-composting with fats $(\mathrm{C}-\mathrm{F}): \mathrm{RS}(14.56 \mathrm{~kg})+$ Fats $(0.56 \mathrm{~kg})+\mathrm{WC}$

Co-composting with protein $(\mathrm{C}-\mathrm{P}): \mathrm{RS}(15.71 \mathrm{~kg})+$ Protein $(0.88 \mathrm{~kg})+\mathrm{WC}$

Co-composting with cellulose $(\mathrm{C}-\mathrm{C}): \mathrm{RS}(13.00 \mathrm{~kg})+$ Cellulose $(1.05 \mathrm{~kg})+\mathrm{WC}$

Initial characteristics of the above mixtures are detailed in tables 2, 3, 4 and 5. As can be observed in these tables, initial AFP, bulk density and moisture content were within the range of appropriate values for composting (Haug, 1993). The percentages of co-substrates (fats, protein and cellulose) were significantly different for each experiment except in the case of protein. Initial protein content in the control experiment and the co-composting experiment with protein added were very similar due to the variability in raw sludge composition (see Table 1). 


\subsection{Experimental Set $U p$}

Experiments were undertaken in a $25 \mathrm{~L}$ insulated and sealed stainless steal cylindrical reactor $(\mathrm{D}=25 \mathrm{~cm}, \mathrm{~h}=50 \mathrm{~cm}$, Cemiflex $\AA$ foam (Cemiflex Spain) insulation) in which process conditions can be controlled. The reactor was placed on a scale (M60, Sertec pesage, Spain) for weight monitoring. Two holes were made at the lid of the reactor: to insert the temperature prove at the centre and to register the outgoing gases. Another hole was placed at the bottom of the reactor to insufflate the inlet air.

On line parameters recorded were: $\mathrm{O}_{2}(\%)$ and $\mathrm{CO}_{2}(\%)$ in interstitial air, material weight and process temperature. Gas content of the outgoing gases was measured using an $\mathrm{O}_{2}$ sensor (Sensox 6C, Sensotran, Spain) and a $\mathrm{CO}_{2}$ infrared detector (Sensotran IR, Sensotran, Spain). Both sensors were placed next to the outgoing gases exit. One Pt sensor (SR-NOH, Desin, Spain) inserted at the centre of the reactor was used for temperature monitoring. A self made data acquisition personal computer system was used to record the three signals.

A continuous air flow was supplied homogeneously in the composting mass using a plastic mesh from the bottom of the reactor and adjusted with a flow meter (MR3A18SVVT, Sensotran, Spain) to maintain oxygen concentration higher than $11 \%$. Inlet air flow was manually adjusted on the basis of oxygen concentration within the range 0.1 and $0.6 \mathrm{~L} \cdot \mathrm{min}^{-1} \cdot \mathrm{kg}^{-1}$ dry matter. Moisture content was analyzed to ensure optimal conditions (40 - 60\%, Haug 1993). In these experiments no water addition was required. 


\subsection{Sampling procedure}

Three samples of $2 \mathrm{~L}$ material were used during each experiment for analysis. The first sample was taken from the initial mixture, the second was taken during the thermophilic temperature peak and a third one was obtained from final material at the end of the process. The sample taken during the thermophilic phase was withdrawn from the central part of the composting mass in the reactor after removing the upper part which was immediately returned to the reactor after sampling. Sampling during the thermophilic phase was carefully done to maintain the physical structure of the material sampled in order to obtain a representative measure of AFP and to avoid any alteration.

\section{$2.4 \quad$ Analytical Methods}

\section{Analytical Methods}

Fats content (FC) was measured using a standard Soxhlet method (U.S. Environmental Protection Agency, 1998) using n-heptane as organic solvent (99\% purity, Panreac, Spain). Additional parameters as Moisture Content (MC), Dry Matter (DM), Total Organic Matter (OM), N-Kjeldhal, Electrical Conductivity (EC), N-NH 4 , Bulk density and $\mathrm{pH}$ were determined according to the standard procedures (U.S. Department of Agriculture and U.S. Composting Council, 2001).

Carbon (\%), nitrogen (\%), protein (\%), hemicellulose (\%) and cellulose+lignin (\%) content were determined from a liophilizated sample (dry matter). Determination of carbon and nitrogen was undertaken by elementary analysis and the protein content was derived from these data multiplying organic nitrogen content by 6.25 . Hemicellulose and cellulose+lignin content were determined following Van Soest methodology (Van Soest and McQueen, 1973). 


\section{Air filled porosity}

Air filled porosity, also referred in literature as Free Air Space, is expressed as the ratio of gas filled pore volume of the sample $\left(\mathrm{V}_{\mathrm{a}}\right)$ to total sample volume $\left(\mathrm{V}_{\mathrm{t}}\right)$. AFP was measured using a self made constant volume air pycnometer according to the description of Annan and White (1999) and Oppenheimer et al. (1996) with an effective sample chamber volume $\left(\mathrm{V}_{\mathrm{t}}\right)$ of $1.65 \mathrm{~L}$ and using an initial pressure of 5 bars. Other works point that AFP measured at high initial pressure includes both free air space and intra-particle voids, the latest not available for microorganisms (Agnew and Leonard, 2002; Su et al., 2006).

\section{Static Respiration Index}

Static Respiration Index (SRI) was determined in a static respirometer according to the original model described by Ianotti et al. (1993) and following the modifications and recommendations given by the U.S. Department of Agriculture and U.S. Composting Council (2001). Assays were run at process temperature at the moment of sampling. A complete description of the equipment and procedure is given elsewhere (Barrena et al., 2005). Three replicates were used in each case (mean values are presented). SRI is expressed as $\mathrm{g} \mathrm{O}_{2} \cdot \mathrm{kg} \mathrm{OM}^{-1} \cdot \mathrm{h}^{-1}$.

\section{Dynamic Respiration Index}

Dynamic Respiration Index, DRI, was on-line determined using Equation (1):

$$
\mathrm{DRI}=\frac{\mathrm{F}\left(20.9-\mathrm{O}_{2, \mathrm{out}}\right)}{\mathrm{M} \cdot 100} \cdot \frac{\mathrm{P} \cdot 32 \cdot 60}{\mathrm{R} \cdot \mathrm{T} \cdot \mathrm{DM} \cdot \mathrm{OM}}(1)
$$


where: DRI is the Dynamic Respiration Index $\left(\mathrm{g} \mathrm{O}_{2} \cdot \mathrm{kg} \mathrm{OM}^{-1} \cdot \mathrm{h}^{-1}\right)$; F, the air flow into the reactor $\left(\mathrm{L} \cdot \mathrm{min}^{-1}\right) ; \mathrm{O}_{2, \text { out }}$, the oxygen concentration in the exhaust gases $(\%$, mol $\left.\mathrm{O}_{2} \cdot \mathrm{mol}^{-1}\right) ; \mathrm{M}$, the total mass of waste in the reactor $(\mathrm{kg}) ; \mathrm{P}$, the atmospheric pressure at the elevation of measurement (atm); 32, the oxygen molecular weight $\left(\mathrm{g} \mathrm{O}_{2} \cdot \mathrm{mol} \mathrm{O}_{2}{ }^{-1}\right)$; 60 , the conversion factor from minutes to hours; 20.9 , the percentage of oxygen in inlet air; $\mathrm{R}$, the ideal gas constant $\left(0.08206 \mathrm{~L} \cdot \mathrm{atm} \cdot \mathrm{mol}^{-1} \cdot \mathrm{K}^{-1}\right)$; $\mathrm{T}$, temperature $(\mathrm{K})$; DM, the fraction of dry matter of a parallel sample aliquot $\left(\mathrm{kg} \mathrm{DM} \cdot \mathrm{kg}^{-1}\right)$ and $\mathrm{OM}$, the fraction of total organic matter of a parallel sample aliquot in dry basis $\left(\mathrm{kg} \mathrm{OM} \cdot \mathrm{kg} \mathrm{DM}{ }^{-1}\right)$.

\subsection{Data analysis}

Statistical significance of values obtained for different parameters reductions shown in Figure 2 for the four composting experiments was carried out by means of F-test (variance analysis) and t-Student test (mean analysis) both at 5\% level of probability.

\section{RESULTS AND DISCUSSION}

\subsection{Control experiment (C)}

This experiment was carried out as a blank test (no co-substrate added to the sludge) for the three co-composting processes run subsequently. Figure 1a shows the temperature, SRI and DRI profiles obtained for experiment C. As can be observed, profiles show how an easily biodegradable material, such as RS adequately conditioned (AFP, MC) is degraded and stabilized in a short period of time (Haug, 1993). A maximum temperature of $55^{\circ} \mathrm{C}$ was achieved within days 2 and 4 of process. DRI and temperature show similar profiles, which is typical of a composting process. Maximum values of 
DRI were registered at day $2\left(2.7 \mathrm{~g} \mathrm{O}_{2} \cdot \mathrm{kg} \mathrm{OM}^{-1} \cdot \mathrm{h}^{-1}\right)$ coinciding with maximum temperature values. SRI of the sample taken during the thermophilic peak was $2.9 \mathrm{~g}$ $\mathrm{O}_{2} \cdot \mathrm{kg} \mathrm{OM}{ }^{-1} \cdot \mathrm{h}^{-1}$. SRI and DRI are indirect measures of the biological activity in a material. SRI indicates the biological potential activity of the material under study, ensuring a controlled and homogeneous aeration as well as adequate moisture. DRI, also known as OUR (Oxygen Uptake Rate), measures the biological activity of the composting material in situ, under operation conditions, indicating the real biological activity developed in the composting process (Gea et al., 2006b). Values of DRI close to values of SRI indicate that the composting process occurs under adequate conditions for microbial activity. Values obtained for DRI in experiment $\mathrm{C}$ were very close to those for SRI in the samples analyzed indicating that the composting process was developed under adequate conditions for biological decomposition. Final values of SRI and DRI indicate the stabilization of the material during the composting process (Adani et al., 2003).

Main results obtained for the different chemical and physical properties in experiment $\mathrm{C}$ are shown in Table 2. Overall reductions calculated for the main parameters are summarized in Table 6. Nitrogen content of the initial mixture was high (3.4\%), because of RS properties (Table 1). As a result, an initial $\mathrm{C} / \mathrm{N}$ ratio of 11 was obtained which is below the optimum suggested (25-30) for most types of waste in composting processes (Haug, 1993). This might have promoted nitrogen losses mainly in the form of $\mathrm{NH}_{3}$ in the exhaust gases. In fact, nitrogen content of the mixture decreased during the process as $\mathrm{N}^{-\mathrm{NH}_{4}}$ concentration increased. According to this increment, a rise in $\mathrm{pH}$ values was also observed. Nitrogen losses were of $40 \%$ and occurred mainly at the beginning of the thermophilic period of temperature as can be 
calculated from initial and thermophilic phase nitrogen percentages in Table 2. In other studies, nitrogen losses were shown to be related to high temperatures and air flow rates during the first days of the process (Pagans et al., 2006).

Protein in the mixture decreased $(40 \%)$ during the process as expected for an easily biodegradable compound in a biological decomposition process such as composting. The reduction on fats content was lower (28\%) according to the relative biodegradability of these compounds. No changes in cellulose+lignin content were detected during the control experiment while hemicellulose decreased by $11 \%$. Other studies have shown that hemicellulose and lignin require longer composting periods for levels to be reduced significantly (Charest et al., 2004).

AFP and wet bulk density followed reverse patterns: AFP decreased during the thermophilic period and increased at the end of the process $(34 \%)$ while wet bulk

density increased and finally decreased to a value of $0.58 \mathrm{~kg} \cdot \mathrm{L}^{-3}$ (Table 2) similar to initial values. This fact can be attributed to organic matter degradation and moisture losses. Correlations within AFP, wet and dry bulk density and moisture content have been previously reported (Agnew and Leonard, 2002; Mohee and Mudhoo, 2005). Material compaction was also observed with a $17 \%$ volume reduction of the material in the reactor during the thermophilic phase, which would explain the initial increase in bulk density.

\subsection{Co-composting with fats (C-F)}

This experiment was carried out with commercial animal fats added to RS. Figure $1 \mathrm{~b}$ shows the temperature, SRI and DRI profiles obtained for C-F. It was not possible to calculate DRI values from day 7 to the end of the composting process due to a failure of 
the $\mathrm{O}_{2}$ sensor. Maximum temperature achieved was $62^{\circ} \mathrm{C}$ coinciding with the highest values registered for DRI (over $6 \mathrm{~g} \mathrm{O}_{2} \cdot \mathrm{kg} \mathrm{OM}^{-1} \cdot \mathrm{h}^{-1}$ ). The value obtained for SRI from the sample taken during the thermophilic period was $4 \mathrm{~g} \mathrm{O}_{2} \cdot \mathrm{kg} \mathrm{OM}^{-1} \cdot \mathrm{h}^{-1}$, similar to DRI values at that moment. The two values of the respiration indices were clearly higher than the values obtained in the control experiment due to the higher energetic content provided by the addition of fats. Values of DRI are very similar to values of SRI as occurred in experiment $\mathrm{C}$, demonstrating again that experiment $\mathrm{C}-\mathrm{F}$ took place under adequate conditions for biological activity.

Experiment C-F presented a high temperature value in the maturation phase. This fact can be related to the high energetic content and slow biodegradability of fats which provoke heat release for a long period of time and thus higher temperatures sustenance. This behavior has been previously observed when composting fat or oil enriched wastes (Alburquerque et al., 2006b; Manios et al., 2006). The percentage of fats added to the composting mixture in those works and the scale of the experiments led to different thermophilic phase duration. Studies have shown that a high degradation of fats (up to $80 \%$ ) could be achieved in the co-composting process (Lemus and Lau, 2002; GarcíaGómez et al., 2003). In Table 6 the reductions in the main parameters are presented as percentages. The fats content was reduced in a $66 \%$ in experiment C-F. In contrast a $28 \%$ reduction was observed in experiment C. It is possible that fats originally present in sludge contain a recalcitrant fraction of non biodegradable lipidic substances. Réveillé et al. (2003) found a fraction of lipids trapped in the humic matrix of composted sludge. To confirm this hypothesis a detailed chemical composition of sludge related to the lipidic substances would be necessary. 
The use of fats, which are a carbon source, as co-substrate improved the $\mathrm{C} / \mathrm{N}$ ratio from 11 (control) to 18 , which clearly resulted in a high nitrogen conservation. Nitrogen content in $\mathrm{C}-\mathrm{F}$ was reduced by $28 \%$ of the initial $\mathrm{N}$ in the composting mixture while in experiment $\mathrm{C}$ this value was a $40 \%$ (Figure 2). A $5 \%$ reduction of hemicellulose content was half of the hemicellulose reduction for experiment C. On the other hand, a $12 \%$ reduction of cellulose + lignin content was observed in C-F experiment which was probably due to the higher temperatures and microbial activity maintained during the entire process. The co-metabolism of these compounds by the microbial communities that grow in this process has been pointed before (Manios et al., 2006). The improvement on fats and other organic materials degradation at high contents of fats (up to 50\%) in the initial mixture has also been reported (Nakasaki et al., 2004).

The addition of fats to a composting mass is recommended in case of low energetic content of the material to be treated to achieve and maintain thermophilic temperatures. It is also recommended in case of carbon lack to balance the initial $\mathrm{C} / \mathrm{N}$ ratio and to improve the degradation of some slowly biodegradable components. However, if fats of animal origin are added to the composting process to improve material biodegradation legal requirements for animal by-products composting should be considered. In European Union, the Regulation 1774/2002 of the European Parliament and of the Council (European Union, 2002) divides animal by-products into different groups attending their potential risks for human health and establishes suitable treatments for each group. Animal residues that can contain prion proteins responsible for bovine spongiform encephalopathy (BSE) are classified into category 1 (high risk), while category 3 includes animal by-products from meat and fish preparation for human consumption (low risk). As low risk materials, residues in category 3 can be treated by 
composting. However specific requirements for material hygienization should be accomplished in those cases, a temperature of $70^{\circ} \mathrm{C}$ should be maintained for at least 1 hour. The present experiment does not fulfill these requirements as the maximum temperature achieved was $62^{\circ} \mathrm{C}$. However, an increment in the percentage of fats added can lead to higher temperatures in the thermophilic period (Gea et al., 2006a). In addition, experiences with other materials at industrial scale demonstrate that the temperatures achieved are higher than those registered at laboratory scale. Although composting of risk animal by-products is not permitted, there are some works about the effectiveness of thermophilic bacteria to degrade abnormal prion protein present in animal tissues (Huang et al., 2007). Suzuki et al. (2006) pointed that the degradation of prion proteins not always leads to their inactivation and to reduce their infectivity.

On the other hand, animal fats can be substituted by fats of vegetal origin as those produced as wastes in the olive oil extraction process (Manios et al., 2006; Roig et al., 2006).

$\mathrm{pH}$ values increased during the experiment from an initial value of 6.7 (lower than C) to a final value of 8.42 . This increment correlates well with the increase detected in $\mathrm{N}-\mathrm{NH}_{4}$ concentration which rises from an initial value of $0.44 \mathrm{mg} \mathrm{NH} \mathrm{N}_{4} \cdot \mathrm{g}^{-1}$ of dry matter to a final value of $1.39 \mathrm{mg} \mathrm{NH} \cdot \mathrm{g}^{-1}$.

AFP and wet bulk density followed the same pattern observed in experiment $\mathrm{C}$ with a highest final value of AFP (56\%) probably due to the high degradation of fats observed. AFP decreases during the thermophilic phase probably due to the melting of the fats and the formation of liquefied fats caused by the high temperatures in the composting vessel. The liquefied fats occupied part of the air filled porosity in the mixture. Also, an $11 \%$ reduction in the volume of the composting mixture was 
registered in the first stage in experiment C-F. The degradation of fats and other organic compounds lead to a final increase of AFP.

\subsection{Co-composting with protein $(\mathrm{C}-\mathrm{P})$}

Figure 1c shows the temperature, SRI and DRI profiles obtained for C-P. Main characteristics of the initial mixture and the results obtained for the different chemical and physical properties of C-P are shown in Table 4. As can be observed, the protein content of the mixture with the added protein was comparable to that of experiment $\mathrm{C}$ (control). This can be due to the intrinsic variability of the initial properties of the sludge used.

SRI maximum value measured $\left(3 \mathrm{~g} \mathrm{O}_{2} \cdot \mathrm{kg} \mathrm{OM}^{-1} \cdot \mathrm{h}^{-1}\right)$ was very similar to the value obtained in the control experiment. Initial value of SRI was slightly higher in C-P than in C. Also values for DRI were higher in C-P than in C (indicating a higher composting potential for the C-P mixture). This observation is supported by the temperature profile as the maximum temperature achieved in $\mathrm{C}-\mathrm{P}\left(67^{\circ} \mathrm{C}\right)$ was higher than the maximum observed in $\mathrm{C}$ and was maintained for a longer period. As observed in control experiment SRI and DRI values were very similar indicating appropriate conditions for microbial activity.

Fats, protein and hemicellulose degradation is observed along the process. As can be seen in Figure 2, reductions of those components are respectively 55\%, 55.8\% and 21.9\%. Cellulose and lignin levels did not change during the decomposition process.

In spite of the fact that $\mathrm{C} / \mathrm{N}$ ratio and initial nitrogen content in experiments $\mathrm{C}$ and C-P were very similar, higher nitrogen losses $(55.8 \%$ of the initial nitrogen in the mixture) were detected in C-P. This fact can be related to the biological availability of 
the nitrogen originally present in the sludge which is supposed to be lower than that of the nitrogen directly added in form of peptone (Gavala et al., 2003). Thus, protein based residues can be used to balance $\mathrm{C} / \mathrm{N}$ ratio of nitrogen deficient materials. Protein wastes can also improve biological activity and thus temperatures reached.

$\mathrm{pH}$ and conductivity values registered during experiment $\mathrm{C}-\mathrm{P}$ were the highest compared with the rest of the experiments. These values correlate with $\mathrm{N}-\mathrm{NH}_{4}$ content of the mixture that was also the highest as can be expected from initial $\mathrm{C} / \mathrm{N}$ ratio and $\mathrm{N}$ concentration.

AFP and wet bulk density for C-P followed a similar pattern as compared to the control experiment where the highest AFP (60\%) had the lowest reduction in the composting mass volume.

\subsection{Co-composting with cellulose (C-C)}

Figure $1 \mathrm{~d}$ shows the temperature, SRI and DRI profiles obtained for C-C. Initial and maximum SRI values ( 3 and $5 \mathrm{~g} \mathrm{O}_{2} \cdot \mathrm{kg} \mathrm{OM}^{-1} \cdot \mathrm{h}^{-1}$ respectively) were higher than those for the control experiment. This fact is probably due to the differences in the physical structure of the initial mixture in spite of maintaining the same value of AFP. In fact, it was noticed that the paper paste added to the sludge acted not only as a co-substrate but also as a bulking agent, increasing the available surface area and improving the microorganism's activity. In previous works, sludge from the paper industry has been successfully composted without the addition of bulking agent due to the physical structure of this paper derived waste (Gea et al., 2005). Maximum value obtained for both SRI and DRI was around $5 \mathrm{~g} \mathrm{O}_{2} \cdot \mathrm{kg} \mathrm{OM}^{-1} \cdot \mathrm{h}^{-1}$. This was reached within days 2 and 4 of process coinciding with the maximum temperature $\left(62^{\circ} \mathrm{C}\right)$. 
Main results obtained for different chemical and physical properties in $\mathrm{C}-\mathrm{C}$ are shown in Table 5. As paper paste added acts as a source of carbon, the initial $\mathrm{C} / \mathrm{N}$ ratio increased slightly (14.5) respect to control. Nitrogen losses (Figure 2) were 35.5\%, slightly lower than in control (40\%). A decrease in fats $(34.8 \%)$, protein $(35.5 \%)$ and hemicellulose $(17.7 \%)$ content in the mixture was observed while the amount of cellulose and lignin did not change significantly.

An increment in the $\mathrm{pH}$ was also observed in this case as was the increment in $\mathrm{N}$ $\mathrm{NH}_{4}$ concentration.

As in the control experiment, AFP and wet bulk density varied inversely during the composting process. A $16 \%$ material volume reduction was registered.

\subsection{Experiments comparison}

Temperature profiles presented in Figure 1 provide clear evidence that higher temperatures were obtained in all co-composting experiments (C-F, C-P and C-C) as compared to the single sludge composting process $(\mathrm{C})$. This shows that the addition of a biodegradable co-substrate has a positive effect on the composting experiments especially for pathogen reduction purposes. Pathogen reduction should be ensured by means of adequate time and temperature combination if the final material obtained from the composting process has to be applied to soil (Gea et al., 2007). Co-substrates added to low energy materials may be adopted as a solution to fulfill legislation requirements in these cases. C-P was the experiment showing the maximum temperature $\left(67^{\circ} \mathrm{C}\right)$ and during which high temperature was maintained longer.

Addition of a co-substrate resulted in higher microbial activity and this observation was supported by the respiration indices (DRI and SRI). Values for initial 
SRI were higher in experiments $\mathrm{C}-\mathrm{F}$ and $\mathrm{C}-\mathrm{C}$ than in $\mathrm{C}$ and $\mathrm{C}-\mathrm{P}$. Also SRI values at thermophilic range were higher for $\mathrm{C}-\mathrm{F}$ and $\mathrm{C}-\mathrm{C}$, while $\mathrm{C}$ and $\mathrm{C}-\mathrm{P}$ presented a similar value. This fact was corroborated by DRI values for which $\mathrm{C}-\mathrm{F}$ experiment presented the highest values in the thermophilic phase followed by C-C. It is important to notice that the initial value obtained for SRI is a good indicator for the material's proneness to degradation in an aerobic decomposition process as composting. The similarity in the values of SRI and DRI in the points where both were measured has also to be highlighted. Similar values of DRI and SRI indicate adequate composting conditions for biological activity development. This fact demonstrates the importance of an adequate initial conditioning of the composting mixture. In our case, initial conditioning was done by means of an optimum AFP value that ensures an adequate $\mathrm{O}_{2}$ availability for microorganisms which is crucial in an aerobic decomposition process such as composting. Lack of sufficient $\mathrm{O}_{2}$ would promote anaerobic degradation.

Final SRI values were lower than $0.5 \mathrm{~g} \mathrm{O}_{2} \cdot \mathrm{kg} \mathrm{OM}^{-1} \cdot \mathrm{h}^{-1}$, and indicator of compost stability, in all the experiments except for $\mathrm{C}-\mathrm{C}$. There is no general consensus in the value of the respiration indices that ensures compost stability. However, a value of 0.4$0.5 \mathrm{~g} \mathrm{O}_{2} \cdot \mathrm{kg} \mathrm{OM}^{-1} \cdot \mathrm{h}^{-1}$ for SRI has been proposed by different authors and legislation (Adani et al., 2002; Adani et al., 2003; Iannoti et al., 1993).

As stated previously, Figure 2 shows the main total reductions (\%) obtained in all the experiments. Weight, DM, OM and C reductions were significantly higher in all cocomposting experiments than in control experiment, except for C-P dry matter reduction. Therefore, co-composting is a more efficient process than sludge composting process. 
In relation to the reduction percentages of the different biochemical fractions, fats content reduction obtained in $\mathrm{C}-\mathrm{F}$ was the highest. A correlation has been found $(p<0.01)$ between the amount of fats initially present in the composting mixture and the amount of fats degraded during the process, indicating that an increment in fats content will lead to an increment in fats degradation. On the other hand, protein reduction was also higher in C-P where commercial protein was added. Although a mathematical correlation could not be established in this case, a clear tendency is observed relating to the increment in the degradation of both fats and protein when their percentage in the composting mixture increases. This fact may indicate that microbial communities present are stimulated by a particular substrate (Gousterova et al., 2005).

The reduction of hemicellulose fraction was much higher for C-P and C-C than for control and C-F. Degradation of cellulose + lignin fraction was only detected in C-F experiment where a $12 \%$ reduction was obtained for this fraction. As stated above, Manios et al. (2006) reported the degradation of cellulose and lignin in composting experiments with oil enriched wastes and attributed this fact to the high temperatures achieved and maintained for long periods of time. In our case, C-F experiment shows the higher temperatures in the mesophilic phase. That fact can enhance cellulose and lignin degradation.

The addition of a co-substrate as $\mathrm{C}$ source ( $\mathrm{C}-\mathrm{F}$ and $\mathrm{C}-\mathrm{C}$ experiments) partially compensates the low $\mathrm{C} / \mathrm{N}$ ratio of the sludge and enhances the nitrogen conservation (significantly lower nitrogen reduction percentages as presented in Figure 2).

In all experiments a compactation of the organic matrix was observed in the first days of composting with volume reductions from initial to thermophilic phase of $17 \%$ (C), $11 \%(\mathrm{C}-\mathrm{F}), 6 \%(\mathrm{C}-\mathrm{P})$ and $16 \%(\mathrm{C}-\mathrm{C})$. Material compaction provoked an AFP 
reduction in most of the cases. Afterwards, AFP values recovered once the biodegradation of organic matter progressed without changes in the matrix volume. Final AFP was higher than initial AFP for the 3 co-composting experiments but this was not observed in $\mathrm{C}$. This fact can be related to the higher percentages of organic matter degradation obtained in the co-composting experiments.

\section{CONCLUSIONS}

The co-composting process of raw sludge with different co-substrates presents important differences compared to the composting process of raw sludge. Some advantages should be highlighted as the increase in microbiological activity (observed in the values of SRI and DRI) and pathogen reduction potential of the material.

Values of DRI were very close to values of SRI indicating that the composting process took place under adequate conditions for biological activity.

As demonstrated by DRI and SRI values, AFP is a necessary parameter to adjust physical properties of the initial mixture.

Higher degradation percentages were obtained during co-composting experiments for weight, dry matter and organic matter content as compared to raw sludge composting. Addition of fats resulted in high fats degradation percentages and promoted the reduction of recalcitrant compounds as lignin.

Adding co-substrates to the sludge as carbon sources enhanced nitrogen conservation in the treated materials. 


\section{Acknowledgements}

The authors wish to thank Dr. Xavier Flotats for the cession of the composting reactor used in these experiments. Financial support was provided by the Spanish Ministerio de Medio Ambiente (Project 185/2006/3-4.3).

\section{REFERENCES}

Adani F, Lozzi P, Genevini P (2001) Determination of biological stability and oxygen uptake rate on municipal solid waste and derived products. Compost Sci Util 9:163-178.

Adani F, Ubbiali C, Tambone F, Scaglia B, Centenero M, Genevini P (2002) Static and dynamic respirometric indices - Italian research and studies. In: The Biological Treatment of Biodegradable Waste - Technical aspects. Brussels 8-10 April. http://europa.eu.int/comm/environment/waste/eventspast/bio_programme.htm. Consulted 14 Nov 2006.

Adani F, Gigliotti G, Valentini F, Laraia R (2003). Respiration index determination: A comparative study of different methods. Compost Sci Util 11:144-151.

Adani F, Ubbilai C, Genevini P (2006). The determination of biological stability of compost using the Dynamic Respiration Index: The results of experience after two years. Waste Manage 26:41-48.

Agnew JM, Leonard JJ (2002) Using a modified pycnometer to determine free air space and bulk density of compost mixtures while simulating compressive loading. In: Michel 
FC, Rynk RF, Hoiting HAJ (eds.) Proceedings of the International Symposium Compost and Compost Utilisation, Biocycle, Columbus (Ohio).

Alburquerque JA, Gonzálvez J, García D, Cegarra J (2006a) Effects of bulking agent on the composting of "alperujo", the solid by-product of the two-phase centrifugation method for olive oil extraction. Process Biochem 41:127-132.

Alburquerque JA, Gonzálvez J, García D, Cegarra J (2006b) Composting of a solid olive-mill by-product ("alperujo") and the potential of the resulting compost for cultivating pepper under commercial conditions. Waste Manage 26:620-626.

Annan J, White R (1999) Evaluation of techniques for measuring air filled porosity in compost of municipal biosolids and wood chips. AWARE Environmental, Inc., North Carolina (USA).

Baddi GA, Alburquerque JA, Gonzálvez J, Cegarra J, Hafidi M (2004) Chemical and spectroscopic analyses of organic matter transformations during composting of olive oil mill wastes. International Biodeterioration \& Biodegrgadation 54:39-44.

Barrena R, Vázquez F, Gordillo MA, Gea T, Sánchez A (2005) Respirometric assays at fixed and process temperatures to monitor composting process. Bioresource Technol 96:1153-1159. 
Barrena R, Vázquez F, Sánchez A (2006) The use of respiration indices in the composting process: a review. Waste Manage Res 23:1-11.

Charest MH, Antoun H, Beauchamp CJ (2004) Dynamics of water soluble carbon substances and microbial populations during the composting of de-inking paper sludge. Bioresource Technol 91:53-67.

Díaz MJ, Madejón E, Ariza J, López R, Cabrera F (2002) Cocomposting of beet vinasse and grape marc in windrows and static pile systems. Compost Sci Util 10:258-269.

European Union (2002) Regulation (EC) No 1774/2002 of the European Parliament and of the Council of 3 October 2002 laying down health rules concerning animal byproducts not intended for human consumption. URL http://europa.eu/scadplus/leg/en/lvb/f81001.htm.

García-Gómez A, Roig A, Bernal MP (2003) Composting of the solid fraction of olive mill wastewater with olive leaves: organic matter degradation and biological activity. Bioresource Technol 86:59-64.

Gavala HN, Yenal U, Skiadas IV, Westermann P, Ahring BK (2003) Mesophilic and thermophilic anaerobic digestion of primary and secondary sludge. Effect of pretreatment at elevate temperature. Wat Res 37:4561-4572. 
Gea T, Artola A, Sánchez A (2003) Application of the experimental design technique to the optimization of bench-scale composting conditions of municipal raw sludge. Compost Sci Util 11:321-329.

Gea T, Artola A, Sánchez A (2005) Composting of de-inking sludge from the recycled paper manufacturing industry. Bioresource Technol 96:1161-1167.

Gea T, Ferrer P, Álvaro G, Valero F, Artola A, Sánchez A (2006a) Co-composting of sewage sludge:fats mixtures and characteristics of the lipases involved. Biochem Eng $\mathbf{J}$ $33: 275-283$.

Gea T, Barrena R, Ruggieri L, Artola A, Sánchez A (2006b) Monitoring the biological activity of the composting process of multiple wastes. In: Kraft E, Bilingmaier W, de Bertoldi M, Diaz LF, Barth J (eds) Proceedings of 5th International Conference ORBIT 2006, Weimar, 2006.

Gea T, Barrena R, Artola A, Sánchez A (2007) Optimal bulking agent particle size and usage for heat retention and disinfection in domestic wastewater sludge composting. Waste Manage 27:1108-1116.

Gousterova A, Braikova D, Goshev I, Christov P, Tishinov K, Vasileva-Tonkova E, Haertle T, Nedkov P (2005) Degradation of keratin and collagen containing wasted by newly isolated thermoactinomycetes by alkaline hydrolysis. Letters Appl Microbiol 40:335-340. 
Haug RT (1993) The practical handbook of compost engineering. Lewis Publishers, Boca Raton, FL.

Huang HS, Spencer JL, Soutyrine A, Guan JW, Rendulich J, Balachandran A (2007) Evidence for degradation of abnormal prion protein in tissues from shep with scrapie during composting. Can J Vet Res 71:34-40.

Iannotti DA, Pang T, Toth BL, Elwell DL, Keener HM, Hoitink HAJ (1993) A quantitative respirometric method for monitoring compost stability. Compost Sci Util $1: 52-65$.

Komilis DP (2006) A kinetic analysis of solid waste composting at optimal conditions. Waste Manage 26:82-91.

Lemus GR, Lau AK (2002) Biodegradation of lipidic compounds in synthetic food wastes during composting. Canadian Biosystems Eng 44:33-39.

Liang Y, Leonard JJ, Feddes JJR, McGill WB (2006) Influence of carbon and buffer amendment on ammonia volatilization in composting. Bioresource Technol 97:784-761.

Malinska KA, Richard TL (2006) The impact of physical properties and compaction on biodegradation kinetics during composting. In: Kraft E, Bilingmaier W, de Bertoldi M, 
Diaz LF, Barth J (eds) Proceedings of 5th International Conference ORBIT 2006, Weimar, 2006.

Manios T, Maniadakis K, Kalogeraki M, Mari E, Stratakis E, Terzakis S, Boytzakis P, Naziridis Y, Zampetakis L (2006) Efforts to explain and control the prolonged thermophilic period in two-phase olive oil mill sludge composting. Biodegradation $17: 285-292$.

Mohee R, Mudhoo A (2005) Analysis of the physical properties of an in-vessel composting matrix. Powder Technol 155:92-99.

Nakasaki K, Nagasaki K, Ariga O (2004) Degradation of fats during thermophilic composting of organic waste. Waste Manage Res 22:276-282.

Oppenheimer J, Martin J, Walker L (1996) Measurements of air filled porosity in unsaturated organic matrices using a pycnometer. Bioresource Technol 59:241-247.

Pagans E, Barrena R, Font X, Sánchez A (2006) Ammonia emissions from the composting of different organic wastes. Dependency on process temperature. Chemosphere 62:1534-1542.

Paredes C, Bernal MP, Cegarra J, Roig A (2002) Bio-degradation of olive mill wastewater sludge by its co-composting with agricultural wastes. Bioresource Technol $85: 1-8$ 
Roig A, Cayuela ML, Sánchez-Monedero MA (2006) An overview on olive mill wastes and their valorisation methods. Waste Manage 26:960-969.

Réveillé V, Mansuy L, Jardé E, Garnier-Sillam E (2003) Characterisation of sewage sludge-derived organic matter: lipids and humic acids. Org Geochem 34:615-627.

Sánchez A (2007) A kinetic analysis of solid waste composting at optimal conditions. Waste Manage 27:854-855.

Saviozzi A, Cardelli R, Levi-Minzi R, Riffaldi R (2004) Evolution of biochemical parameters during composting of urban wastes. Compost Sci Util 12:153-160.

Su D, McCartney D, Wang Q (2006) Comparison of Free Air Space Test Methods. Compost Sci Util 14:103-113.

Suzuki Y, Tsujimoto Y, Matsui H, Watanabe K (2006) Decomposition of extremely hard-to-degrade animal proteins by thermophilic bacteria. J Biosci Bioeng 102:73-81.

Tiquia SM (2005) Microbiological parameters as indicators of compost maturity. J Appl Microbiol 99:816-828.

Tremier A, de Guardia A, Massiani C, Paul E, Martel JL (2005). A respirometric method for characterising the organic composition and biodegradation kinetics and the 
temperature influence on the biodegradation kinetics, for a mixture of sludge and bulking agent to be co-composted. Bioresource Technol 96:169-180.

U.S. Department of Agriculture and U.S. Composting Council (2001) Test methods for the examination of composting and compost. Edaphos International, Houston, TX.

U.S. Environmental Protection Agency (1995) A Guide to the Biosolids Risk $\begin{array}{llllll}\text { Assessments for the } & \text { PPA }\end{array}$ http://www.epa.gov/owm/mtb/biosolids/503rule/. Consulted 14 Nov 2006.

U.S. Environmental Protection Agency (1998) Method 9071B. http://www.epa.gov/sw846/pdfs/9071b.pdf. Consulted 14 Nov 2006.

Van Soest PJ, McQueen RW (1973) The chemistry and estimation of fibre. Proc Nutr Soc 32:123.

Zhang S, Herbell JD, Gaye-Haake B (2004) Biodegradable organic matter in municipal solid waste incineration bottom ash. Waste Manage 24:673-679. 


\section{Captions to Figures}

Figure 1: a) Composting of Sludge (C), b) Co-composting of Sludge and Fats (C-F), c) Co-composting of Sludge and Proteins (C-P) and d) Co-composting of Sludge and Cellulose (C-C).

Figure 2: Total reductions obtained for the main parameters in the different experiments. Different letters show statistical significance of the differences observed for reduction values of each property. 
Figure 1
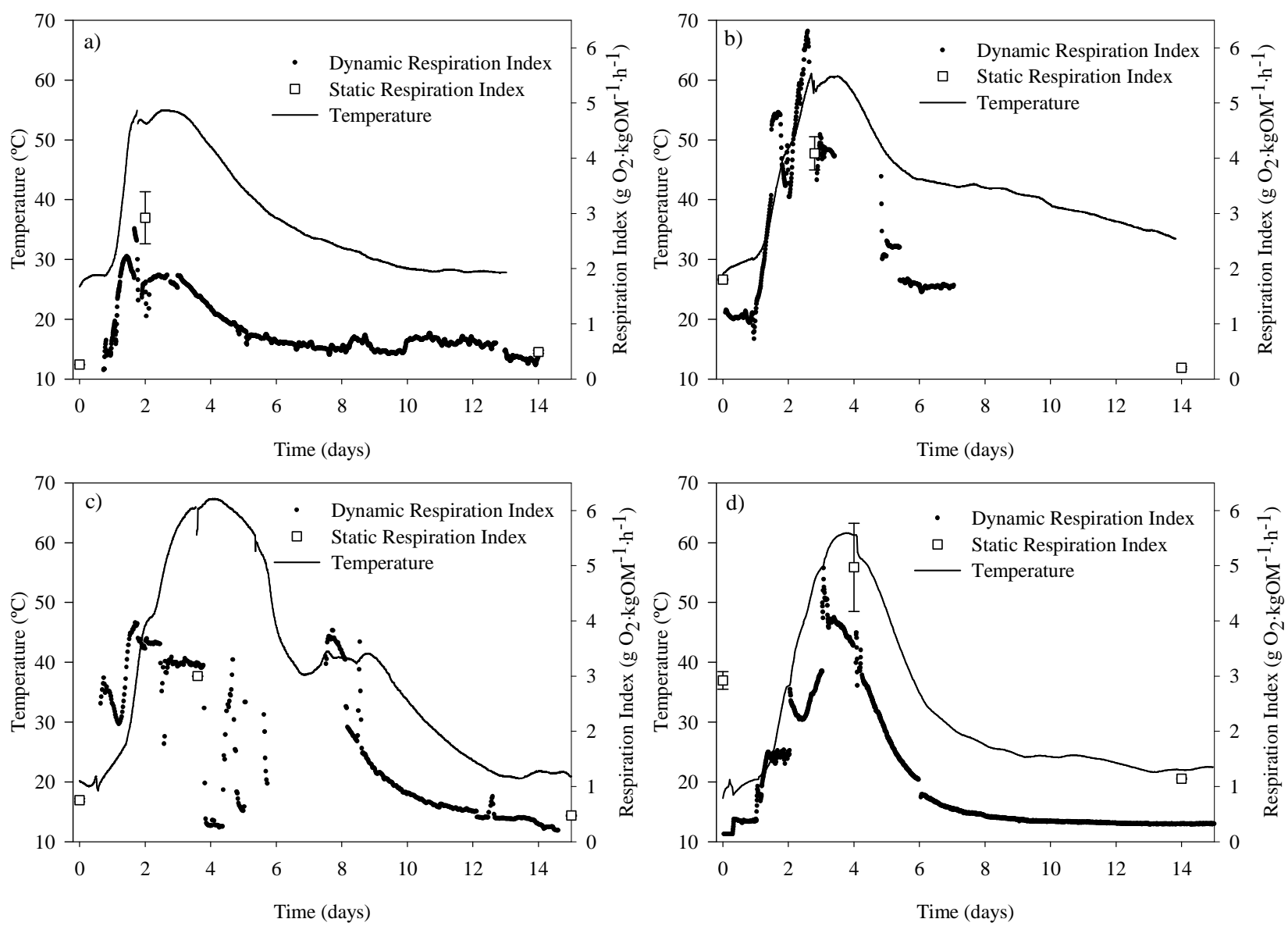
Figure 2

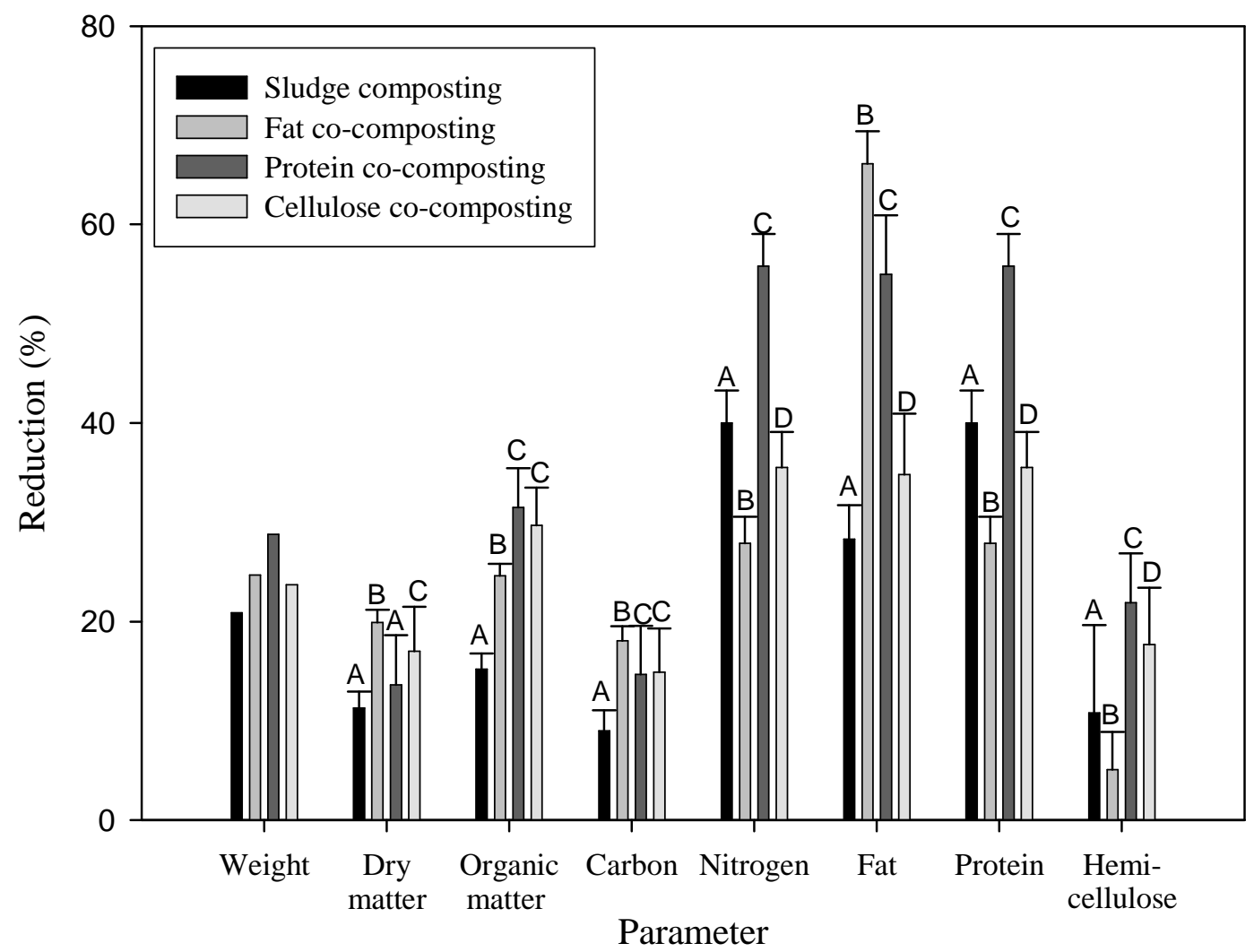




\section{Tables}

Table 1: Main characteristics of raw sludge (RS)

\begin{tabular}{lc}
\hline Property & Mean value \\
\hline Moisture Content (\%) & $85.4 \pm 2.7$ \\
Dry Matter (\%) & $14.6 \pm 2.7$ \\
Organic Matter (\% dry basis) & $73.4 \pm 9.1$ \\
$\mathrm{~N}(\%$ dry basis) & $7.7 \pm 0.9$ \\
$\mathrm{C} / \mathrm{N}$ & $4.9 \pm 1.1$ \\
$\mathrm{pH}$ & $7.0 \pm 0.7$ \\
Conductivity (mS cm & \\
Air filled porosity $(\%)$ & $2.5 \pm 1$ \\
\hline
\end{tabular}


Table 2: Experiment C, Sludge Composting.

\begin{tabular}{|c|c|c|c|}
\hline Property & Initial & Thermophilic Phase & Final \\
\hline Weight (kg) & 12.9 & 12.8 & 10.2 \\
\hline Moisture Content (\%) & $50.2 \pm 0.8$ & $47.4 \pm 0.1$ & $44.1 \pm 0.8$ \\
\hline Dry Matter (\%) & $49.8 \pm 0.8$ & $52.7 \pm 0.1$ & $55.9 \pm 0.8$ \\
\hline Organic Matter (\%) & $74.4 \pm 1.5$ & $72.9 \pm 0.5$ & $71.1 \pm 0.1$ \\
\hline $\mathrm{C}(\%)$ & $38.12 \pm 0.66$ & $39.88 \pm 0.93$ & $39.11 \pm 0.1$ \\
\hline $\mathrm{N}(\%)$ & $3.40 \pm 0.13$ & $2.17 \pm 0.14$ & $2.30 \pm 0.14$ \\
\hline $\mathrm{C} / \mathrm{N}$ & 11.22 & 18.41 & 17.02 \\
\hline Fats content $(\%)$ & $2.90 \pm 0.13$ & $2.99 \pm 0.05$ & $2.32 \pm 0.01$ \\
\hline Protein $(\%)$ & $21.24 \pm 0.82$ & $13.54 \pm 0.87$ & $14.38 \pm 0.88$ \\
\hline Hemicellulose (\%) & $16.34 \pm 3.44$ & $17.90 \pm 8.16$ & $17.00 \pm 2.48$ \\
\hline Cellulose + Lignin $(\%)$ & $31.59 \pm 1.69$ & $36.02 \pm 4.61$ & $43.78 \pm 1.13$ \\
\hline $\operatorname{AFP}(\%, v / v)$ & $44.5 \pm 1.4$ & $25.2 \pm 1.4$ & $34.4 \pm 0.1$ \\
\hline Bulk density $\left(\mathrm{kg} \cdot \mathrm{L}^{-1}\right)$ & 0.58 & 0.65 & 0.58 \\
\hline $\mathrm{pH}$ & $7.22 \pm 0.04$ & $8.23 \pm 0.29$ & $8.86 \pm 0.08$ \\
\hline $\mathrm{N}-\mathrm{NH}_{4}\left(\mathrm{mg} \cdot \mathrm{g}^{-1}\right)$ & $0.02 \pm 0.00$ & $0.20 \pm 0.07$ & $0.20 \pm 0.01$ \\
\hline Conductivity $\left(\mathrm{mS} \mathrm{cm}^{-1}\right)$ & $2.65 \pm 0.40$ & $3.60 \pm 0.72$ & $5.01 \pm 0.34$ \\
\hline
\end{tabular}


Table 3: C-F, Sludge and Fats Co-composting.

\begin{tabular}{|c|c|c|c|}
\hline Property & Initial & Thermophilic Phase & Final \\
\hline Weight (kg) & 11.75 & 11.55 & 8.85 \\
\hline Moisture Content (\%) & $58.8 \pm 0.1$ & $59 \pm 0.03$ & $56 \pm 0.8$ \\
\hline Dry Matter (\%) & $41.2 \pm 0.1$ & $41 \pm 0.03$ & $44 \pm 0.8$ \\
\hline Organic Matter (\%) & $74.2 \pm 0.1$ & $74.0 \pm 0.0$ & $69.8 \pm 0.1$ \\
\hline $\mathrm{C}(\%)$ & $44.45 \pm 0.21$ & $47.50 \pm 0.28$ & $45.45 \pm 0.49$ \\
\hline $\mathrm{N}(\%)$ & $2.48 \pm 0.05$ & $2.45 \pm 0.05$ & $2.23 \pm 0.10$ \\
\hline $\mathrm{C} / \mathrm{N}$ & 17.92 & 19.38 & 20.36 \\
\hline Fats content $(\%)$ & $10.61 \pm 0.37$ & $7.34 \pm 0.02$ & $4.49 \pm 0.57$ \\
\hline Protein $(\%)$ & $15.50 \pm 0.29$ & $15.32 \pm 0.31$ & $13.95 \pm 0.60$ \\
\hline Hemicellulose (\%) & $13.50 \pm 0.78$ & $14.20 \pm 1.68$ & $15.53 \pm 0.63$ \\
\hline Cellulose + Lignin $(\%)$ & $44.87 \pm 0.75$ & $47.96 \pm 0.54$ & $49.10 \pm 0.21$ \\
\hline $\operatorname{AFP}(\%, \mathrm{v} / \mathrm{v})$ & $39.93 \pm 2.11$ & $27.96 \pm 2.11$ & $56.04 \pm 2.11$ \\
\hline Bulk density $\left(\mathrm{kg} \cdot \mathrm{L}^{-1}\right)$ & 0.62 & 0.69 & 0.61 \\
\hline $\mathrm{pH}$ & $6.7 \pm 0.01$ & $7.2 \pm 0.02$ & $8.42 \pm 0.31$ \\
\hline $\mathrm{N}-\mathrm{NH}_{4}\left(\mathrm{mg} \cdot \mathrm{g}^{-1}\right)$ & $0.44 \pm 0.04$ & $1.41 \pm 0.06$ & $1.39 \pm 0.05$ \\
\hline Conductivity $\left(\mathrm{mS} \mathrm{cm}^{-1}\right)$ & $2.74 \pm 0.01$ & $2.94 \pm 0.08$ & $2.71 \pm 0.10$ \\
\hline
\end{tabular}


Table 4: C-P, Sludge and Protein Co-composting.

\begin{tabular}{|c|c|c|c|}
\hline Property & Initial & Thermophilic Phase & Final \\
\hline Weight (kg) & 14.40 & 14.25 & 10.25 \\
\hline Moisture Content (\%) & $66.46 \pm 2.2$ & $63 \pm 0.4$ & $59 \pm 0.8$ \\
\hline Dry Matter (\%) & $33.5 \pm 2.2$ & $37.0 \pm 0.4$ & $41.0 \pm 0.8$ \\
\hline Organic Matter (\%) & $73.9 \pm 0.5$ & $63.9 \pm 2.8$ & $58.6 \pm 1.3$ \\
\hline $\mathrm{C}(\%)$ & $43.45 \pm 0.64$ & $42.55 \pm 0.35$ & $42.90 \pm 0.57$ \\
\hline $\mathrm{N}(\%)$ & $3.38 \pm 0.17$ & $2.16 \pm 0.03$ & $1.73 \pm 0.08$ \\
\hline $\mathrm{C} / \mathrm{N}$ & 12.85 & 19.71 & 24.85 \\
\hline Fats content $(\%)$ & $4.66 \pm 0.04$ & $2.90 \pm 0.69$ & $2.43 \pm 0.40$ \\
\hline Protein $(\%)$ & $21.13 \pm 1.06$ & $13.50 \pm 0.16$ & $10.79 \pm 0.49$ \\
\hline Hemicellulose (\%) & $14.85 \pm 0.30$ & $15.91 \pm 1.90$ & $13.53 \pm 0.65$ \\
\hline Cellulose + Lignin $(\%)$ & $42.52 \pm 0.21$ & $50.25 \pm 0.70$ & $56.76 \pm 0.09$ \\
\hline $\operatorname{AFP}(\%, v / v)$ & $37.63 \pm 4.98$ & $39.47 \pm 1.59$ & $60.64 \pm 0.80$ \\
\hline Bulk density $\left(\mathrm{kg} \cdot \mathrm{L}^{-1}\right)$ & 0.68 & 0.52 & 0.59 \\
\hline $\mathrm{pH}$ & $8.0 \pm 0.4$ & $8.8 \pm 0.6$ & $9.4 \pm 0.0$ \\
\hline $\mathrm{N}-\mathrm{NH}_{4}\left(\mathrm{mg} \cdot \mathrm{g}^{-1}\right)$ & $0.9 \pm 0.04$ & $1.84 \pm 0.06$ & $1.59 \pm 0.05$ \\
\hline Conductivity $\left(\mathrm{mS} \mathrm{cm}^{-1}\right)$ & $5.68 \pm 0.41$ & $6.05 \pm 0.96$ & $4.53 \pm 0.59$ \\
\hline
\end{tabular}


Table 5: C-C, Sludge and Cellulose Co-composting.

\begin{tabular}{|c|c|c|c|}
\hline Property & Initial & Thermophilic Phase & Final \\
\hline Weight (kg) & 13.90 & 13.90 & 10.60 \\
\hline Moisture Content (\%) & $69.92 \pm 1.7$ & $66.89 \pm 0.03$ & $66.8 \pm 0.9$ \\
\hline Dry Matter (\%) & $30.1 \pm 1.7$ & $33.1 \pm 0.0$ & $33.2 \pm 0.9$ \\
\hline Organic Matter (\%) & $71.4 \pm 0.0$ & $62.4 \pm 0.0$ & $60.5 \pm 0.0$ \\
\hline $\mathrm{C}(\%)$ & $38.20 \pm 0.14$ & $37.40 \pm 0.42$ & $39.15 \pm 0.07$ \\
\hline $\mathrm{N}(\%)$ & $2.63 \pm 0.04$ & $2.12 \pm 0.08$ & $2.04 \pm 0.05$ \\
\hline $\mathrm{C} / \mathrm{N}$ & 14.55 & 17.60 & 19.20 \\
\hline Fats content $(\%)$ & $4.12 \pm 0.37$ & $3.47 \pm 0.18$ & $3.22 \pm 0.20$ \\
\hline Protein $(\%)$ & $16.41 \pm 0.27$ & $13.28 \pm 0.48$ & $12.74 \pm 0.32$ \\
\hline Hemicellulose (\%) & $13.74 \pm 0.88$ & $12.37 \pm 2.35$ & $13.72 \pm 1.00$ \\
\hline Cellulose + Lignin $(\%)$ & $38.18 \pm 0.23$ & $43.35 \pm 0.68$ & $43.44 \pm 0.65$ \\
\hline $\operatorname{AFP}(\%, \mathrm{v} / \mathrm{v})$ & $45.91 \pm 1.38$ & $35.79 \pm 0.80$ & $56.04 \pm 2.11$ \\
\hline Bulk density $\left(\mathrm{kg} \cdot \mathrm{L}^{-1}\right)$ & 0.58 & 0.65 & 0.63 \\
\hline $\mathrm{pH}$ & $7.2 \pm 0.1$ & $9.2 \pm 0.1$ & $9.1 \pm 0.0$ \\
\hline $\mathrm{N}-\mathrm{NH}_{4}\left(\mathrm{mg} \cdot \mathrm{g}^{-1}\right)$ & $0.32 \pm 0.00$ & $1.25 \pm 0.03$ & $1.39 \pm 0.05$ \\
\hline Conductivity $\left(\mathrm{mS} \mathrm{cm}^{-1}\right)$ & $2.36 \pm 0.20$ & $3.37 \pm 0.47$ & $3.40 \pm 0.42$ \\
\hline
\end{tabular}

